\title{
Community Genetics
}

No. 1

1 Editorial

ten Kate, L.P. (Amsterdam)

Reviews

2 Ethical Issues in Molecular Screening for Heterozygous Familial Hypercholesterolemia: The Complexity of Dealing with Genetic Susceptibility to Coronary Artery Disease

Gaudet, D.; Gagné, C. (Chicoutimi/Sainte-Foy); Perron, P. (Chicoutimi); Couture, P. (Sainte-Foy); Tonstad, S. (Oslo)

9 Prenatal Screening and the Reduction of Birth

Defects in Populations

Baird, P.A. (Vancouver)

Original Papers

18 Down Syndrome and Parity

Clementi, M. (Padova); Bianca, S. (Catania); Benedicenti, F.; Tenconi, R. (Padova); and the Working Group on Down Syndrome

23 Analysis of the Population Structure in Oman

Rajab, A. (Muscat); Patton, M.A. (London)

26 Screening for Alpha-Thalassemia-1 Heterozygotes in Expecting Couples by the Combination of a Simple Erythrocyte Osmotic Fragility Test and a PCR-Based Method

Sanguansermsri, T.; Phumyu, N.; Chomchuen, S.; Steger, H.F. (Chiang Mai)

30 Genetic, Epidemiologic and Social Features of Colour Blindness Tagarelli, A.; Piro, A.; Tagarelli, G. (Mangone)

36 Study of 290 Cases of Polyhydramnios and Congenital Malformations in a Series of 225,669 Consecutive Births Stoll, C.G.; Roth, M.-P.; Dott, B.; Alembik, Y. (Strasbourg)

Commentaries

43 The UK's Policies on Genetic Testing for Late-Onset Disorders Holtzman, N.A. (Baltimore, Md.)

46 Commissioning Clinical Genetic Services in the UK Kääriäinen, H. (Helsinki)

Letters to the Edito

47 Development and Use of a National Haemoglobinopathy Register in Oman

Rajab, A. (Muscat); Patton, M.A. (London)

49 Screening for Female Fragile $X$ Premutation and Full Mutation Carriers. A Commentary on the Work of Wildhagen et al. Tejada, M.I.; Duran, M. (Bilbao)
No. 2-3

Review

51 Archived Specimens: A Platform for Discussion Wertz, D.C. (Waltham, Mass.)

Original Papers

61 Assessment of Two 'Low-Tech' Genetic Health Care Procedures Performed by Prenatal Care Providers in Washington State: Implications for Future Policy Development Activities Fineman, R.M.; Bell, T.M. (Seattle, Wash.)

69 First-Cousin Matings and Congenital Heart Disease in Saudi Arabia

Becker, S.; Al Halees, Z. (Riyadh)

74 Preconceptional Screening of Couples for Carriers of Cystic Fibrosis: A Prospective Evaluation of Effects, Costs and Savings for Different Mutation Detection Methods Verheij, J.B.G.M. (Groningen); Wildhagen, M.F. (Rotterdam); Hofstra, R.M.W. (Groningen); Pals, G. (Amsterdam); Habbema, J.D.F. (Rotterdam); Ten Kate, L.P. (Amsterdam)

82 Carrier Testing Program in a High-Risk Cystic Fibrosis Population from Northeastern Italy. Active Recruitment of Relatives via Probands' Parents

Borgo, G.; Castellani, C.; Bonizzato, A.; Rolfini, R.; Altieri, S.; Zanolla, L.; Mastella, G. (Verona)

91 Glycogen Storage Disease Type II: Birth Prevalence Agrees with Predicted Genotype Frequency

Ausems, M.G.E.M.; Ten Berg, K. (Utrecht); Kroos, M.A.; Van Diggelen, O.P. (Rotterdam); Wevers, R.A. (Nijmegen); Poorthuis, B.J.H.M. (Leiden); Niezen-Koning, K.E (Groningen); Van der Ploeg, A.T. (Rotterdam); Beemer, F.A. (Utrecht); Reuser, A.J.J. (Rotterdam); Sandkuijl, L.A (Utrecht/Rotterdam); Wokke, J.H.J. (Utrecht)

97 Birth Defect and Risk Factor Surveillance in the Northern and Southwestern Netherlands

Reefhuis, J. (Groningen); Zandwijken, G.R.J. (Rotterdam) De Walle, H.E.K.; Cornel, M.C. (Groningen)

109 Maternal Serum Screening for Down Syndrome: A Survey of Pregnant Women's Views

Paravic, J.; Brajenoviç-Milic, B. (Rijeka); Tišlaric, D. (Zagreb); Kapoviç, M. (Rijeka); Botica, A.; Jurcan, V.; Milotti, S. (Rijeka)

Opinions

113 Qualifications of Public Health Geneticists? Fineman, R.M. (Seattle, Wash.)

115 Knowledge about Medical Genetics in Health Care Harris, R.; Harris, H. (Manchester)

Abstracts

119 Report on the Second National Conference on Genetics and Public Health

118 Announcements

\section{KARGER}

Fax + 41613061234 E-Mail karger@karger.ch www.karger.com
(C) 2000 S. Karger AG, Basel

Access to full text and tables of contents, including tentative ones for forthcoming issues: www.karger.com/journals/ccg/ccg_bk.htm 
No. 4

International Conference on Community Genetics,

'From DNA to the Community' Programme and Abstracts

137 From DNA to the Community

Conference on Community Genetics

Jonquière, Québec, Canada, June 20-22, 2000

Organizer: Gaudet, D. (Jonquière)

138 Congress Committee

139 Introduction

140 Programme

145 Abstracts

155 Author Index for Abstracts

Review

156 The Role of Voluntary Consumer Organisations in Genetic Services in the United Kingdom

Kent, A. (London)

Commentary

162 Common Language for Measures of Occurrence of Congenital Anomalies and Genetic Diseases: Incidence or Birth Prevalence Cornel, M.C. (Groningen)

Original Papers

165 French Physicians' Knowledge about Hereditary Breast/Ovarian Cancer: The Need for Continuing Vocational Training in Genetics Julian-Reynier, C.; Eisinger, F.; Moatti, J.-P.; Sobol, H. (Marseille)

173 Prevalence of Pedigrees Suggestive of Hereditary Nonpolyposis Colorectal Cancer among a Community Sample of Women Eligible for Screening Mammography Ramsey, S.D. (Seattle, Wash.); Freedman, A.N. (Rockville, Md.); Berry, K.; Andersen, M.R.; Urban, N. (Seattle, Wash.)
179 The Epidemiology of Myotonic Dystrophy in Northern Ireland Magee, A.; Nevin, N.C. (Belfast)

184 Etiological Characterization of 512 Severely Mentally Retarded Institutionalized Patients in Havana

Lantigua-Cruz, A.; Mora, F.; Arechaederra, M.; Rojas, I.; Morales, E.; Rodríguez, H.; Viñas, C.; Noa, C.E.; Barrios, B. (Havana)

190 Living with Machado-Joseph Disease in a Small Rural Community of the Tagus Valley

Paúl, C.; Martín, I. (Porto); do Rosário Silva, M.; Silva, M. (Chamusca); Coutinho, P.; Sequeiros, J. (Porto)

Report

196 Services for the Prevention and Management of Genetic Disorders and Birth Defects in Developing Countries

Penchaszadeh, V.B. (New York, N.Y.); Christianson, A.L. (Pretoria); Giugliani, R. (Porto Alegre); Boulyjenkov, V. (Geneva); Katz, M. (White Plains, N.Y.)

202 Book Review

203 Announcements

204 Acknowledgement to the Reviewers

206 Author Index Vol. 2, 1999

208 Subject Index Vol. 2, 1999 